\title{
International Egyptian Journal of Nursing Sciences and Research
}

(IEJNSR)

Received 2021-11-20

Original Article

\section{Effect of Educational Program on Nurse's Knowledge, Practice and Attitude Regarding Covid -19 at Maternity Care Units}

\author{
Mona Ahmed Abd-Elhamed ${ }^{1}$, Magda Fawzy Hasab Allah ${ }^{2}$ \\ $(1,2)$ Lecturer of Woman Health and Obstetrics Nursing, Faculty of Nursing -Minia University.
}

\begin{abstract}
COVID-19 pandemic remains a worldwide challenge. Healthcare providers including maternity nurses fighting on the frontlines. Issues as knowledge, awareness of mode of disease transmission, basic hygiene principles and measures will help support them and safeguard lives of everyone. Aim of this study: to evaluate the effect of educational program on nurse's knowledge, practice and attitude regarding Covid 19 at maternity care units Subjects and Methods: Quasi- experimental study design was used; study was conducted at Minia university hospital for maternity and child. A convenient sample of seventy nurses was included. Data were collected using a structured interviewing questionnaire sheet contained a series of questions regarding nurses knowledge, attitude, and practice (KAP) about COVID-19. In addition to, a supportive material (guidelines) was distributed to the studied sample. Results: This study revealed that nurses had lower knowledge scores $(32.9 \%)$ in pre-program which increased to $(90.0 \%)$ in post-program after the program, $(58.6 \%)$ of them had negative attitude pre-program while post-program decreased to $(18.6 \%)$ and $(84.3 \%)$ had incompetent practice pre-program while post-program decreased to $(18.6 \%)$ with highly statistically significance differences $P$ - value .0001 . Conclusion: applying educational program about COVID-19 for maternity nurses was effective in increasing their knowledge, improves infection control measures, change negative attitudes, and improve practices. Recommendations: Apply further wide range educational programs for whole nursing staff, nursing supervisors, and workers.
\end{abstract}

Keywords: Maternity, Knowledge, Attitude, Practice, COVID-19.

\section{Introduction}

The COVID-19 pandemic remains a worldwide challenge. In spite of extreme study efforts globally, the effective treatment, and vaccine options have eluded the investigators. Thus, the strategies like infection prevention protocols, early viral detection, and identification of effective treatment could offer significant tools in the controlling of the spread of this disease. (Lotfi, et al 2020)

New coronavirus (COVID-19) is the world's most popular name and it is the focus of the interest of many scientists, researchers, politicians, and general people worldwide especially because of the surprisingly increasing burden of the disease. (Guan et al., 2020).

As of 4 August 2020, there are currently over 18 million people globally affected by COVID-19 with over 700,000 deaths reported worldwide, and rising. In Egypt, from Jan 3 to 25 December 2020, there have been 128,993 confirmed cases of COVID-19 with 7,260 deaths. (World Health Organization 2020)

COVID- 19 is the new strains of viruses which can infect humans. The current COVID-19 pandemic caused so many reported cases around the world. The mode of transmission of COVID 19 viruses are 
transmitted from person-to-person and similar to seasonal influenza and may cause the same symptoms. (Louay, et al., 2020).

Coronaviruses cause mild respiratory tract infections such as the common cold. The clinical symptoms of COVID-19-infected patients may include high temperature, dry cough, abnormal chest CT, and less common symptoms as sputum production, headache, hemoptysis, and diarrhea. severe acute respiratory syndrome-related coronavirus (COVID-19) is an extremely infectious viral respiratory disease resulting in pneumonia (Rothan \& Byrareddy, 2020) \& World Health Organization (WHO), 2020).

The infection has taken $80 \%$ of countries of the world in a short time, created hardships and challenges. COVID-19 has been decreed as a deadly infection and speeded like wildfire in different nations. According to current evidence, the COVID-19 virus is transmitted between people through respiratory droplets and contact routes. Droplet transmission occurs when a person is in close contact (within $1 \mathrm{~m}$ ) with someone who has respiratory symptoms (e.g. coughing or sneezing,) and is therefore at risk of having his/her mucosae (mouth and nose) or conjunctiva (eyes) exposed to potentially infective respiratory droplets (which are generally considered to be $>5-10 \mu \mathrm{m}$ in diameter) (Shahnaz, et al., 2020).

Nurses are the largest healthcare profession in the world, with approximately 20 million nurses worldwide. Nurses should have awareness and knowledge of the disease and infection control measures to prevent spread. However, empirical data reports COVID-19 is challenging to nurses due to the novelty of the disease, this lack of information, training, and seminars to care for patients with the virus, and the psychological trauma resulting from patient deaths. Since it is such a new infection, misunderstanding COVID-19 signs and symptoms and incorrect treatment by nurses might speed the spread of hospital infection (Lancet, 2020)

Health education programs play an important role in improving COVID-19 knowledge and helpful for encouraging an optimistic attitudes and maintaining safe practices (Zhong et al., 2020).

Healthcare workers have a critical role in reducing morbidity and mortality but in doing so they are directly prone to patients and the causative agents. Preventing nosocomial infections and protecting healthcare workers posed great challenges to the healthcare system during the initial COVID-19 outbreak in China Maternity nurse is the primary health care provider that provides health education for pregnant women, so the aim of the current study is to evaluate the effect of applied guideline on nurse's knowledge and practice regarding Covid- 19 at maternity care units (Wang et al., 2019).

\section{Significance of the study}

In July 2020, 11,191,676 cases and 529,127 deaths have been reported globally. Europe is the most affected region with 2,638,903 cases and the highest number of deaths 196,169 . The African region is least affected with 268,102 cases and 5,673 deaths (CSSE, 2020). In Egypt, from Jan 3 to 25 December 2020, there have been 128,993 confirmed cases of COVID-19 with 7,260 deaths. (World Health Organization 2020)

The International Council of Nurses' latest analysis shows that the number of nurses who have died after contracting COVID-19 is 1,500. Around 10 per cent of all cases globally are health-care workers, the ICN's analysis suggests, meaning more than two million health-care workers worldwide could have been infected with COVID-19 (Said, 2020) 
The maternity healthcare providers and facilities hence need to prepare for the situation with a view to prevent the consequences of the infection on themselves, the mother and her new-born.

\section{Aim of the Study:}

The aim of the present study was to evaluate the effect of educational program on nurse's knowledge, attitude and practice regarding COVID-19 at maternity care units.

\section{Research hypotheses:}

1. Nurses who received evidence based practices guidelines will have improvement in their knowledge, attitude and practice regarding covid-19.

2. There will be significant correlation between nurses' knowledge with their practices regarding care of maternity women during covid-19.

3. There will be significant correlation between posttest knowledge, attitude and practice scores of nurses with their selected socio-demographic characteristics.

\section{Subjects and Methods}

\section{Research design:-}

Quasi-experimental research design (pre and post intervention) was utilized in this study.

\section{Setting of the study:}

This study was carried out at obstetrics, labor, gynecological and other units at Minia university hospital for maternity and child. The Hospital serving not only Minia city but also the whole Minia centers ( 9 centers) and it's villages. The Hospital consists of 4 floors, the ground floor contains card and neonate registration offices, X-ray, MRI and free trading pharmacy, and the 1st floor contains, pediatric clinic, antenatal care clinic, infertility clinic operating rooms and private department. The 2nd floor contains gynecological department, intensive care unit and laboratory services, the 3rd floor contains antenatal, high risk pregnancy department, delivery and postpartum rooms, and the 4th floor contains pediatric department and intensive care unit. The hospital works all of the day but the out patient's clinics works from 9 A.M to 1 P.M.

\section{Sampling:}

\section{Sample size}

A convenient sample was used, All nurses (70 nurses) who work in obstetrics (11 nurses), labor (18nurses), gynecological (12 nurses), private operations room (7 nurses), major operations room (9 nurses), obstetric triage (7 nurses) and private obstetric (6 nurses) departments, who work in the previously mentioned setting from (June - October 2020).

Exclusion criteria: Nurses who are in long vocation at the time of data collection (as child care leave, vocation without pay...)

\section{Data Collection Tools:}

A specially designed self-administered questionnaire was developed and utilized by the researchers to collect the necessary data from the nurses based on relevant literature, the questionnaire was reviewed and validated by the Jury committee that was composed of a panel of 5 experts of Obstetrics and Gynecological Nursing professors (Minia and Ain shams Universities) who reviewed the tool for clarity, relevance, comprehensiveness, understanding, applicability and considered the aim of this study

\section{Three tools for gathering data were used in the study:}

\section{Tool I: A self-administered Questionnaire:}

A specially designed self-administered questionnaire was developed and utilized by the 
researchers to collect the necessary data from the nurses and consisted of two parts as follow:

\section{Part (1): Socio-demographic characteristics}

Including age, educational level, and duration of work, place of residence and attendance of training courses.

Part (11): Nurses knowledge about Covid-19 Infection: To evaluate the Knowledge of nurses about covid19 such as: source of information regarding COVID-19, mode of transmission, symptoms, and characteristics of covid19, prevention and control of the disease,..etc.

Scoring system for knowledge: Knowledge consists of 26 questions, were either in the form of a multiple choice answer or in form of true, false, These questions were given scores (1 or zero) it was assigned to each answer representing (complete correct, or incorrect respectively). Overall knowledge scores were categorized as: Unsatisfactory: $(<70 \%)(0-18.1)$, satisfactory: $(\geq 70 \%)(18.2-26)$.

Tool II: Nurses attitudes toward Covid-19 Infection (pre/post) (Nwafor et al., 2020): To evaluate nurses attitude toward covid-19 such as: Is it important to use a face mask in crowded place? It is important to wash hands and face after when provide care for maternity women? And .etc.

Scoring system for attitude: A 3 point Likert scale, ranged from 1 Disagree, 2 Undecided to 3 Agree was applied for the attitude. Total attitude scores were classified as: Positive attitude when nurses answers were $(\geq 70 \%)(37.8-54)$.and negative attitude if their answers were $(<70 \%)(1<37.8)$.

Tool III: Practical observational checklist of maternity nurse about covid-19 (pre/post) (Nebraska Medicine, 2020): This is including questions to evaluate nurse's practice regarding covid-
19 infection. It was included nurse's reported practices during as Follow Special Advices for Covid-19, wash hands at work, use tissues or use elbow during coughing/sneezing? And ...etc.

Scoring system for practice: with a similar scoring system as previous (correct $=2$, incorrect $=0$, no opinion =1). The total score of each nurse was categorized into competent and incompetent practices as follows: incompetent $(<80.0 \%) \quad(0-20)$ and competent ( $\geq 80.0 \%)(20.1-25.0)$.

Validity: The sheet was reviewed by a panel of 5 experts from community health \& obstetrics and gynecological department nursing professors who reviewed the tool for clarity, relevance, comprehensiveness, understanding, applicability and considered the aim of this study.

Reliability: The test assessed through Cronbach's alpha test as the reliability of the questions relating to knowledge was 0.89 , reliability of the questions relating to attitude 0.85 was, and the reliability of the questions relating to reported practice was 0.88 . The tools' reliability was estimated by using the Pearson correlation coefficient test to compare variables

\section{Pilot Study:}

A pilot study was conducted on (7 nurse) $10 \%$ of obstetrics nurse at the previous mentioned setting to assess the current study tools for its clarity, validity and time required to be applied. According to the results of the pilot, all required and necessary modifications done and pilot study excluded in the study

\section{Method of data collection:}

Operational Design: The operational design for the current study included three phases named by preparatory, implementation, and evaluation phase. It was designed to evaluate the effect of instructional 
guidelines on nurse's knowledge, attitude and practices regarding COVID-19 at maternity care units.

\section{Preparatory phase:}

It included reviewing of local and international related literatures about the various aspects of the research problem. This helped researcher to be acquainted with the magnitude of the problems, and guided her to prepare the required data collection tools. Then the researcher tested the validity of the tool through jury of expertise to test the content, knowledge, accuracy $\&$ relevance of questions for tools.

\section{Ethical considerations:}

All formal permits were obtained from convenient authorities to perform the study. The relevance and purpose of this study were discussed with nurses. Who were told that their contribution was voluntary and their right to discontinue at any time, that data confidentiality was achieved, and that the data collected was only used for the purpose of the present study.

\section{Implementation phase:}

After an official permission obtained from the head of the department of Obstetrics in Minia university hospital for maternity and child an approval for data collection to conduct this study. The study was conducted from a period of 5 months from June 2020 to October 2020. At the beginning of interview the researchers greeted each nurse, explained the purpose, duration, and activities of the study and taken written consent. Each nurse will fill questionnaire individually after taking their consent to participate in the study and given an explanation about the nature of the study by the investigators. Data included assessment of the nurse's knowledge, attitude and practice regarding ovid19 infection as baseline data.
The researchers visited the previous mentioned setting in the two shifts (Morning and evening), two days/week. The guideline applied on 6 sessions; 2 sessions for knowledge (each session last from 60-90 minutes), 2 sessions for Attitude (each session last 2 hours) and 2 sessions for practice(each session last 2 hours) ; two sessions per day to cover all theoretical and practical guidelines and implemented according to work conditions. In this phase the nurses were divided into small groups, each subgroup consists of (3-5) nurses. Provided orientation on the guide and its aim at the beginning of the first session, background taken in the beginning of each session regarding previous one.

\section{The Supportive material (handout Arabic booklet- guideline):}

It was designed and utilized by the researchers to enhance nurses' practices to cope with Covid-19 Infection which had positive effect on their attitude and practices. It consisted of two parts; the $1^{\text {st }}$ one concerned with providing the nurses with the essential information about (what is COVID-19, morphology, types, causes, mode of transmission, most common symptoms of COVID 19, vaccination for COVID-19, treatment methods..Etc. While $2^{\text {nd }}$ part concerned with information about nurse's practice, (recommendations for personal habits and hygiene as using tissues or elbow during coughing/sneezing, wash hands frequently using water and soaps, avoid touching face and eyes, rub hands with alcoholic gel during work shift and will providing patients care whether infected or not). And importance to keep their roles as health educator for their patients, colleges and surrounding people.

\section{Outcome follow-up and evaluation phase:}

The investigator conducted 2 time of evaluation: 
- First time of evaluation (pretest) done before implementation of the guideline by using tools I, II,III and IV to assess knowledge, Attitude and practice of the nurse.

- Second time of evaluation (posttest) done after 3 months of the guideline by using tools I,II,III and IV to evaluate guidelines on the nurse's Knowledge, attitude and practice regarding covid19 in maternity care units.

\section{Statistical analysis design:}

The collected data were organized; categorized, analyzed using the statistical package for social studies (SPSS) version (20). (Windows Microsoft). Data were presented using descriptive statistics in form of frequencies and percentages for qualitative variables, mean and standard deviations for quantitative variables. The statistical test such as chi-square test was to determine relation between qualitative data and the comparison between mean scores was performed using Fisher exact and ANOVA test. Statistical significance difference was considered when $\mathrm{p}$-value $\leq 0.05$, and high significance when $p$-value $\leq 0.001$ and no statistical significance difference was considered when $\mathrm{p}$-value $>0.05$.

\section{RESULTS}

Table (1): Illustrates that, $92.9 \%$ of studied sample aged from $22 \geq 27$ years old. Regarding level of education, $82.9 \%$ of them were diploma degree. Concerning to duration of work, $91.4 \%$ of them were 15 years, concerning to attendance of training regarding Covid19 at maternity care unit, $20.0 \%$ of them had previous training and concerning to residence, $62.9 \%$ of them were living in urban areas, while $37.1 \%$ of them live in rural areas.

Figure (1): Shows that $(65.70 \%)$ of the studied sample were taken information about Covid-19 from
T.V/ Radio, (4.30\%) was from beers, and (30.00\%) was other sources (eg. internet, social media, telegram and studding theses epidemic infection in medicine and nursing faculties).

Table (2): shows that, $67.1 \%$ of studied sample had unsatisfactory knowledge pre-program while postprogram decreased to $10.0 \%$ with highly statistically significance differences $\mathrm{P}$ - value $.001,58.6 \%$ of them had negative level of attitude pre-program while postprogram decreased to $18.6 \%$ with highly statistically significance differences $\mathrm{P}$ - value .001. And concerning to their total practice levels regarding Covid19, 84.3\% of studied sample had incompetent practice preprogram while post-program decreased to $18.6 \%$ with highly statistically significance differences $\mathrm{P}$ - value .001

Figure (2): shows that, $32.9 \%$ of studied sample had satisfactory knowledge pre-program while postprogram improved to $90 \%$ with highly statistically significance differences $\mathrm{P}$ - value .001

Figure (3): Shows that, $15.7 \%$ of studied sample had positive level of attitude pre-program while postprogram improved to $81.4 \%$ with highly statistically significance differences $\mathrm{P}$ - value .001 .

Figure (4): Shows that, $15.7 \%$ of the studied sample had competent level of practice pre-program while post-program improved to $81.4 \%$ with highly statistically significance differences $\mathrm{P}$ - value .001 .

Table (3): Shows that, (100.0\% of studied sample who aged from $(32-36), 70.0 \%$ who had B.Scs. degree, $71.4 \%$ of who had attendance of training regarding and $54.2 \%$ who live in urban areas) all had satisfactory knowledge pre-program with statistically significance differences $\mathrm{P}$ - value $\leq(0.027 \& 0.034$, $0.02,0.009,0.001$ and 0.006 . while there was no statistically significance differences between studied 
sample age, educational level, duration of work, attendance of training, and place of residence with their total knowledge in post post-program.

Table (4): Shows that, (100.0\% of studied sample who had duration of work $(10-15), 67.4 \%$ who live in urban areas, respectively) had positive attitude preprogram with statistically significance differences $\mathrm{P}$ value $\leq(0.027 \& 0.038$ respectively $)$. But no statistically significance differences between nurses age, educational level and attendance of training with their total attitude level pre-program. While $100.0 \%$ of studied sample who had attendance of training regarding Covid19 had positive attitude post-program with statistically significance differences $\mathrm{P}$ - value $\leq$ 0.046. But no statistically significance differences between nurses age, educational level, duration of work and place of residence with their total practice post post-program.

Table (5): Shows that, $96.2 \%$ of studied sample who live in urban areas had competence level of practice in pre-\& post-program with statistically significance differences $\mathrm{P}-$ value $\leq(0.036 \& 0.015)$. But no statistically significance differences between nurses age, educational level, duration of work and attendance of training with their total practice in pre-\& post-program.

Table (6): shows that there was a positive fair association between studied sample total knowledge and attitude with their age and duration of work ( $r=$ $0.267 \& p$-value $<0.025 \& r=0.257 \& p$-value $<$ $0.032)$ and $(r=0.252 \& p-$ value $<0.035 \& r=0.260 \&$ $\mathrm{p}-$ value $<0.030$ respectively) pre-program.

Also, there was a positive fair association between studied sample total knowledge with their educational level post-program $(r=0.326 \& p-$ value 0.006 ), positive weak association between nurses attitude with their age post-program and $(r=0.242 \& p$ -value $<0.043$ ), and positive fair association between studied nurses practice and with their age and duration of work $(r=0.343 \& p$-value $<0.004 \& r=0.327 \& p-$ value $<0.006$ respectively) post-program.

Table (7): shows that moderate positive correlation between knowledge scores of the studied sample and their attitude scores pre-program $(r=0.628$, $\mathrm{P}$ value $<0.0001$ ), fair positive correlation between knowledge scores e of the studied sample and their practice scores pre-program $(\mathrm{r}=0.264, \mathrm{P}$ value < 0.0001 ), and between attitude and practice scores preprogram $(\mathrm{r}=0.346, \mathrm{P}$ value $<0.0003)$.

Also, positive correlation between knowledge of the studied sample pre-program and their knowledge, attitude, practices scores post- program $(\mathrm{r}=0.382, \mathrm{P}$ value $<0.001 ; \mathrm{r}=0.337, \mathrm{P}$ value $<0.004 ; \mathrm{r}=0.363, \mathrm{P}$ value $<0.002$ respectively), positive correlation between attitude of the studied sample pre-program and their attitude post-program $(\mathrm{r}=0.369, \mathrm{P}$ value $<0.002)$ and positive correlation between knowledge of the studied sample post-program and their attitude postprogram $(\mathrm{r}=0.381, \mathrm{P}$ value $<0.001)$.

Table (1): Frequency distribution of the studied sample regarding to their socio-demographic characteristics $(\mathbf{n}=\mathbf{7 0})$

\begin{tabular}{|c|c|c|}
\hline Items & No. & \% \\
\hline Age & & \\
\hline $22-<27$ & 65 & 92.9 \\
\hline $27-<32$ & 2 & 2.9 \\
\hline Education level & 3 & 4.2 \\
\hline Diploma & & \\
\hline B.Sc & 58 & 82.9 \\
\hline Masters & 10 & 14.2 \\
\hline 1 -5 & 2 & 2.9 \\
\hline $5-10$ & & \\
\hline $10-15$ & 64 & 91.4 \\
\hline Duration of work & 2 & 2.9 \\
\hline Attendance of training & & 5.7 \\
\hline Yes & 14 & 20.0 \\
\hline No & 56 & 80.0 \\
\hline Place of residence & & \\
\hline Rural & 26 & 37.1 \\
\hline Urban & 44 & 62.9 \\
\hline
\end{tabular}


Figure (1): Percentage distribution of the studied sample regarding to their sources of knowledge regarding Covid-19 $(\mathbf{n}=70)$

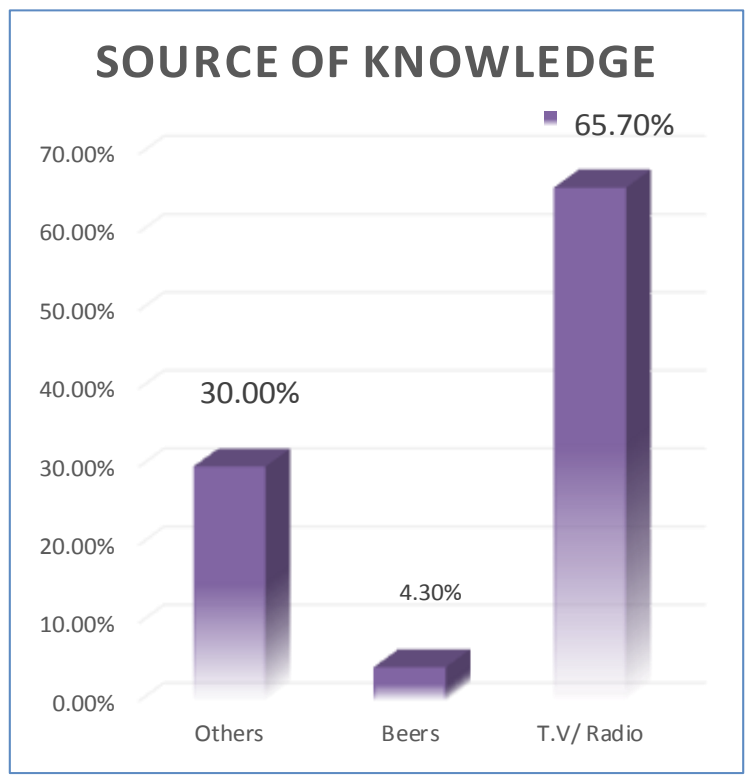

Table (2):percentages destitution of the studied sample regarding to their total Knowledge. Attitude level and Practice about Covid-19 pre and post program. $(\mathbf{n}=\mathbf{7 0})$

\begin{tabular}{|c|c|c|c|c|c|c|}
\hline \multirow[t]{2}{*}{ Items } & \multicolumn{2}{|c|}{$\begin{array}{c}\text { Pre }(\mathbf{n}= \\
70)\end{array}$} & \multicolumn{2}{|c|}{$\begin{array}{c}\text { Post }(\mathbf{n}= \\
70)\end{array}$} & \multicolumn{2}{|c|}{ Test of significance } \\
\hline & No. & $\%$ & No. & $\%$ & $X 2$ & $P$-value \\
\hline \multicolumn{7}{|l|}{ Knowledge } \\
\hline Unsatisfactory & 47 & 67.1 & 7 & 10.0 & \multirow{2}{*}{48.234} & \multirow{2}{*}{$0.0001 * *$} \\
\hline Satisfactory & 23 & 32.9 & 63 & 90.0 & & \\
\hline \multicolumn{7}{|l|}{ Attitude level } \\
\hline Negative & 41 & 58.6 & 13 & 18.6 & \multirow{2}{*}{23.635} & \multirow{2}{*}{$0.0001 * *$} \\
\hline Positive & 29 & 41.4 & 57 & 81.4 & & \\
\hline \multicolumn{7}{|l|}{ Practice } \\
\hline Incompetent & 59 & 84.3 & 13 & 18.6 & \multirow{2}{*}{27.015} & \multirow{2}{*}{$0.0001 * *$} \\
\hline Competent & 11 & 15.7 & 57 & 81.4 & & \\
\hline
\end{tabular}

p>0.05non-significant

$* * p<0.001$ highly significant

Figure (2): Percentage distribution of the studied sample regarding to their total knowledge levels regarding Covid-19 at Maternity Care Units pre and post $\operatorname{program}(\mathbf{n}=70)$.

$100.0 \%$

$50.0 \%$

$0.0 \%$
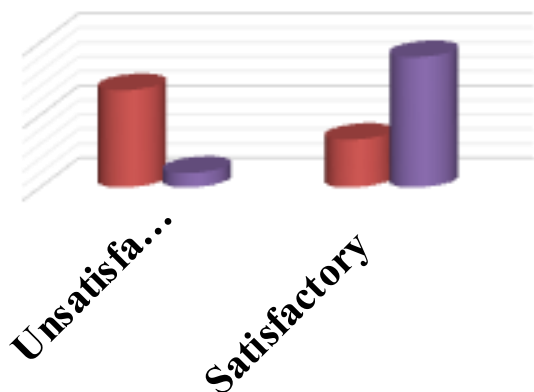

Figure (3): Percentage distribution of the studied sample regarding to their total attitude levels regarding Covid19 at Maternity Care Units pre and post program $(\mathbf{n}=70)$.

$100.0 \%$

$50.0 \%$

$0.0 \%$

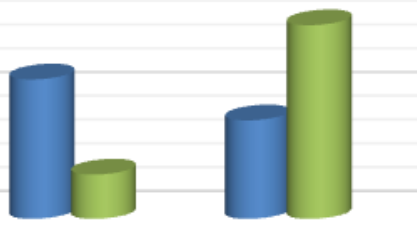

Negative Positive

Figure (4): Percentage distribution of the studied sample regarding to their total practice levels regarding Covid-19 at Maternity Care Units pre and post program. $(\mathbf{n}=\mathbf{7 0})$.

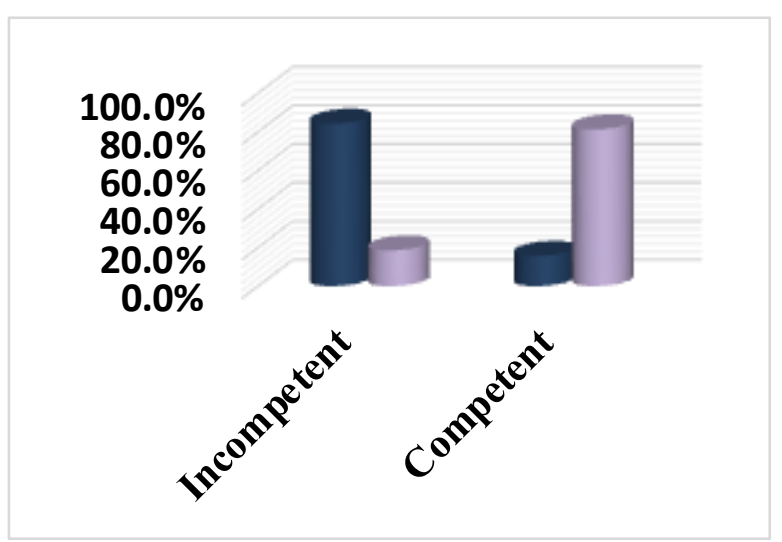

Table (3): Relation between socio-demographic characteristics of the studied sample with their total knowledge levels regarding Covid19 at Maternity Care Units pre/ post$\operatorname{program}(\mathbf{n}=70)$.

\begin{tabular}{|c|c|c|c|c|c|c|c|c|}
\hline \multirow{3}{*}{ Items } & \multicolumn{4}{|c|}{ Total knowledge level (pre) } & \multicolumn{4}{|c|}{$\begin{array}{c}\text { Total knowledge level ( } \\
\text { post) }\end{array}$} \\
\hline & \multicolumn{2}{|c|}{$\begin{array}{c}\text { Satisfactory } \\
(\mathbf{n}=\mathbf{2 3})\end{array}$} & \multicolumn{2}{|c|}{$\begin{array}{c}\text { Unsatisfactory } \\
(n=47)\end{array}$} & \multicolumn{2}{|c|}{$\begin{array}{c}\text { unsatisfactory } \\
(n=7)\end{array}$} & \multicolumn{2}{|c|}{$\begin{array}{c}\text { satisfactory } \\
(\mathbf{n}=63)\end{array}$} \\
\hline & No. & $\%$ & No. & $\%$ & No. & $\%$ & No. & $\%$ \\
\hline \multicolumn{9}{|l|}{ Age } \\
\hline $22-<27$ & 19 & 29.2 & 46 & 70.8 & 7 & 10.8 & 58 & 89.2 \\
\hline $27-<32$ & 1 & 50.0 & 1 & 50.0 & 0 & 0.0 & 2 & 100.0 \\
\hline $32-36$ & 3 & 100.0 & 0 & 0.0 & 0 & 0.0 & 3 & 100.0 \\
\hline Fisher test/ $P-$ value & \multicolumn{4}{|c|}{$6.202(0.034)^{*}$} & \multicolumn{4}{|c|}{$0.509(0.741)$} \\
\hline \multicolumn{9}{|l|}{ Education level } \\
\hline Diploma & 15 & 25.9 & 43 & 74.1 & 7 & 12.1 & 51 & 87.9 \\
\hline B.Sc & 7 & 70.0 & 3 & 30.0 & 0 & 0.0 & 10 & 100.0 \\
\hline Masters & 1 & 50.0 & 1 & 50.0 & 0 & .0 & 2 & 100.0 \\
\hline Fisher test/ $P$-value & \multicolumn{4}{|c|}{$7.589(0.02)^{*}$} & \multicolumn{4}{|c|}{$1.099(0.447)$} \\
\hline \multicolumn{9}{|l|}{ Duration of work } \\
\hline $1-5$ & 19 & 29.7 & 45 & 70.3 & 7 & 10.9 & 57 & 89.1 \\
\hline $5-10$ & 0 & 0.0 & 2 & 100.0 & 0 & 0.0 & 2 & 100.0 \\
\hline $10-15$ & 4 & 100.0 & 0 & 0.0 & 0 & 0.0 & 4 & 100.0 \\
\hline Fisher test/ $P$-value & \multicolumn{4}{|c|}{$8.008(0.009) * *$} & \multicolumn{4}{|c|}{$0.465(0.694)$} \\
\hline \multicolumn{9}{|l|}{$\begin{array}{l}\text { Attendance of } \\
\text { training }\end{array}$} \\
\hline Yes & 10 & 71.4 & 4 & 28.6 & 7 & 12.5 & 49 & 87.5 \\
\hline No & 13 & 23.2 & 43 & 76.8 & 0 & 0.0 & 14 & 100.0 \\
\hline Fisher test/ $P-$ value & \multicolumn{4}{|c|}{$11.802(0.001)^{* * *}$} & \multicolumn{4}{|c|}{$1.944(0.163)$} \\
\hline \multicolumn{9}{|c|}{ Place of residence } \\
\hline Rural & 10 & 21.7 & 36 & 78.3 & 3 & 12.5 & 21 & 87.5 \\
\hline Urban & 13 & 54.2 & 11 & 45.8 & 4 & 8.7 & 42 & 91.3 \\
\hline Fisher test/ $P-$ value & \multicolumn{4}{|c|}{$7.517(0.006)^{* *}$} & \multicolumn{4}{|c|}{$0.254(0.615)$} \\
\hline
\end{tabular}

Percentage done by row

*statistically significance differences at $<0.05$ 
Table (4): Relation between socio-demographic characteristics of the studied sample with their total attitude levels regarding Covid-19 at Maternity Care Units pre/ post $\operatorname{program}(\mathbf{n}=\mathbf{7 0})$.

\begin{tabular}{|c|c|c|c|c|c|c|c|c|}
\hline \multirow{3}{*}{ Items } & \multicolumn{4}{|c|}{$\begin{array}{c}\text { Total attitude level ( } \\
\text { pre) }\end{array}$} & \multicolumn{4}{|c|}{$\begin{array}{r}\text { Total attitude level } \\
\text { ( post) }\end{array}$} \\
\hline & \multicolumn{2}{|c|}{$\begin{array}{c}\text { Negative } \\
(n=41)\end{array}$} & \multicolumn{2}{|c|}{$\begin{array}{c}\text { Positive (n } \\
=29)\end{array}$} & \multicolumn{2}{|c|}{$\begin{array}{c}\text { Negative } \\
(\mathrm{n}=13)\end{array}$} & \multicolumn{2}{|c|}{$\begin{array}{l}\text { Positive } \\
(\mathrm{n}=57)\end{array}$} \\
\hline & No. & $\%$ & No. & $\%$ & No. & $\%$ & No. & $\%$ \\
\hline \multicolumn{9}{|l|}{ Age } \\
\hline $22-<27$ & 40 & 61.5 & 25 & 38.5 & 12 & 18.5 & 53 & 81.5 \\
\hline $27-<32$ & 1 & 50.0 & 1 & 50.0 & 1 & 50.0 & 1 & 50.0 \\
\hline $32-36$ & 0 & 0.0 & 3 & 100.0 & 0 & 0.0 & 3 & 100.0 \\
\hline $\begin{array}{l}\text { Fisher test/ } P- \\
\text { value }\end{array}$ & \multicolumn{4}{|c|}{$4.311(0.103)$} & \multicolumn{4}{|c|}{$1.932(0.370)$} \\
\hline \multicolumn{9}{|l|}{ Education level } \\
\hline Diploma & 34 & 58.6 & 24 & \begin{tabular}{|l|}
41.4 \\
\end{tabular} & 11 & 19.0 & 47 & 81.0 \\
\hline B.Sc & 6 & 60.0 & 4 & \begin{tabular}{|l|}
40.0 \\
\end{tabular} & 1 & 10.0 & 9 & 90.0 \\
\hline Masters & 1 & 50.0 & 1 & \begin{tabular}{|l|}
50.0 \\
\end{tabular} & 1 & 50.0 & 1 & 50.0 \\
\hline $\begin{array}{l}\text { Fisher test/ } P- \\
\text { value }\end{array}$ & \multicolumn{4}{|c|}{$0.382(0.966)$} & \multicolumn{4}{|c|}{$1.983(0.407)$} \\
\hline \multicolumn{9}{|l|}{ Duration of work } \\
\hline $1-5$ & 39 & 60.9 & 25 & 39.1 & 12 & 18.8 & 52 & 81.3 \\
\hline $5-10$ & 2 & 100.0 & 0 & 0.0 & 0 & 0.0 & 2 & 100.0 \\
\hline $10-15$ & 0 & 0.0 & 4 & 100.0 & 1 & 25.0 & 3 & 75.0 \\
\hline $\begin{array}{l}\text { Fisher test/ } P- \\
\text { value }\end{array}$ & \multicolumn{4}{|c|}{$6.397(0.027)^{*}$} & \multicolumn{4}{|c|}{$0.567(0.753)$} \\
\hline \multicolumn{9}{|l|}{$\begin{array}{c}\text { Attendance of } \\
\text { training }\end{array}$} \\
\hline No & 35 & 62.5 & 21 & 37.5 & 13 & 23.2 & 43 & 76.8 \\
\hline Yes & 6 & 42.9 & 8 & 57.1 & 0 & 0.0 & 14 & 100.0 \\
\hline Fisher test/ $P$ - value & \multicolumn{4}{|c|}{$1.781(0.182)$} & \multicolumn{4}{|c|}{$3.991(0.046)^{*}$} \\
\hline \multicolumn{9}{|c|}{ Place of residence } \\
\hline Rural & 10 & 41.7 & 14 & 58.3 & 6 & 25.0 & 18 & 75.0 \\
\hline Urban & 31 & 67.4 & 15 & 32.6 & 7 & 15.2 & 39 & 84.8 \\
\hline Fisher test/ $P$ - value & \multicolumn{4}{|c|}{$4.301(0.038)^{*}$} & \multicolumn{4}{|c|}{$0.998(0.318)$} \\
\hline
\end{tabular}

Table (5): Relation between socio-demographic characteristics of the studied sample with their total practice levels regarding Covid19 at Maternity Care Units pre/ post $\operatorname{program}(\mathbf{n}=70)$.

\begin{tabular}{|c|c|c|c|c|c|c|c|c|}
\hline \multirow{3}{*}{ Items } & \multicolumn{4}{|c|}{$\begin{array}{c}\text { Total practice level } \\
\text { (pre) }\end{array}$} & \multicolumn{4}{|c|}{$\begin{array}{c}\text { Total practice level } \\
\text { (post) }\end{array}$} \\
\hline & \multicolumn{2}{|c|}{$\begin{array}{c}\text { incompetent } \\
(n=59)\end{array}$} & \multicolumn{2}{|c|}{$\begin{array}{c}\text { competent } \\
(\mathrm{n}=11)\end{array}$} & \multicolumn{2}{|c|}{$\begin{array}{c}\text { Competent } \\
(\mathrm{n}=57)\end{array}$} & \multicolumn{2}{|c|}{$\begin{array}{c}\text { Incompetent } \\
(\mathbf{n}=13)\end{array}$} \\
\hline & No. & $\%$ & No. & $\%$ & No. & $\%$ & & \\
\hline \multicolumn{9}{|l|}{ Age } \\
\hline $22-<27$ & 55 & 84.6 & 10 & 15.4 & 53 & 81.5 & 12 & 18.5 \\
\hline $27-<32$ & 2 & 100.0 & 0 & 0.0 & 2 & 100.0 & 0 & 0.0 \\
\hline $32-36$ & 2 & 66.7 & 1 & 33.3 & 2 & 66.7 & 1 & 33.3 \\
\hline $\begin{array}{l}\text { Fisher test/ } P \\
\text { - value }\end{array}$ & \multicolumn{4}{|c|}{$1.437(0.582)$} & \multicolumn{4}{|c|}{$1.121(0.641)$} \\
\hline \multicolumn{9}{|l|}{$\begin{array}{l}\text { Education } \\
\text { level }\end{array}$} \\
\hline Diploma & 50 & 86.2 & 8 & 13.8 & 47 & 81.0 & 11 & 19.0 \\
\hline B.Sc & 7 & 70.0 & 3 & 30.0 & 8 & 80.0 & 2 & 20.0 \\
\hline Masters & 2 & 100.0 & 0 & 0.0 & 2 & 100.0 & 0 & 0.0 \\
\hline $\begin{array}{l}\text { Fisher test/ } P \\
\text { - value }\end{array}$ & \multicolumn{4}{|c|}{$2.043(0.354)$} & \multicolumn{4}{|c|}{$0.361(0.788)$} \\
\hline $\begin{array}{l}\text { Duration of } \\
\text { work }\end{array}$ & & & & & & & & \\
\hline $1-5$ & 54 & 84.4 & 10 & 15.6 & 52 & 81.3 & 12 & 18.8 \\
\hline
\end{tabular}

\begin{tabular}{|c|c|c|c|c|c|c|c|c|}
\hline $5-10$ & 2 & 100.0 & 0 & 0.0 & 2 & 100.0 & 0 & 0.0 \\
\hline $10-15$ & 3 & 75.0 & 1 & 25.0 & 3 & 75.0 & 1 & 25.0 \\
\hline $\begin{array}{l}\text { Fisher test } / P \text { - } \\
\text { value }\end{array}$ & \multicolumn{4}{|c|}{$0.923(0.728)$} & \multicolumn{4}{|c|}{$0.682(0.753)$} \\
\hline \multicolumn{9}{|l|}{$\begin{array}{l}\text { Attendance } \\
\text { of training }\end{array}$} \\
\hline No & 46 & 82.1 & 10 & 17.9 & 44 & 78.6 & 12 & 21.4 \\
\hline Yes & 13 & 92.9 & 1 & 7.1 & 13 & 92.9 & 1 & 7.1 \\
\hline $\begin{array}{l}\text { Fisher test } / P- \\
\text { value }\end{array}$ & \multicolumn{4}{|c|}{$0.971(0.324)$} & \multicolumn{4}{|c|}{$1.511(0.219)$} \\
\hline \multicolumn{9}{|c|}{ Place of residence } \\
\hline \multirow[t]{2}{*}{ Rural } & 25 & 96.2 & 1 & 3.8 & 25 & 96.2 & 1 & 3.8 \\
\hline & 34 & 77.3 & 10 & 22.7 & 32 & 72.7 & 12 & 27.3 \\
\hline $\begin{array}{l}\text { Fisher test/ } P \text { - } \\
\text { value }\end{array}$ & \multicolumn{4}{|c|}{$4.399(0.036)^{*}$} & \multicolumn{4}{|c|}{$5.931(0.015)^{*}$} \\
\hline
\end{tabular}

Percentage done by row

*Statistically significance differences at $<0.05$

Table (6): Correlation between studied sample selective sociodemographics characteristics with total knowledge, attitude, practices scores pre and post- program $(n=$ 70).

\begin{tabular}{|c|c|c|c|c|c|c|c|}
\hline \multicolumn{2}{|c|}{ Items } & \multicolumn{3}{|c|}{ Pre program } & \multicolumn{3}{c|}{ Post program } \\
\cline { 3 - 8 } & & $\begin{array}{c}\text { Knowled } \\
\text { ge }\end{array}$ & $\begin{array}{c}\text { Attitud } \\
\text { e }\end{array}$ & $\begin{array}{c}\text { Practic } \\
\text { e }\end{array}$ & $\begin{array}{c}\text { Knowled } \\
\text { ge }\end{array}$ & $\begin{array}{c}\text { Attitud } \\
\text { e }\end{array}$ & $\begin{array}{c}\text { Practic } \\
\text { e }\end{array}$ \\
\hline \multirow{2}{*}{ Age } & $\mathrm{r}$ & $\mathbf{0 . 2 6 7}$ & $\mathbf{0 . 2 5 2}$ & 0.049 & 0.046 & $\mathbf{0 . 2 4 2}$ & $\mathbf{0 . 3 4 3}$ \\
\cline { 2 - 8 } & $\begin{array}{c}P- \\
\text { value }\end{array}$ & $\mathbf{0 . 0 2 5}$ & $\mathbf{0 . 0 3 5} *$ & 0.684 & 0.703 & $\mathbf{0 . 0 4 3} *$ & $\begin{array}{c}\mathbf{0 . 0 0 4} \\
*\end{array}$ \\
\hline \multirow{2}{*}{$\begin{array}{c}\text { Educati } \\
\text { onal }\end{array}$} & $\mathrm{r}$ & 0.131 & 0.124 & 0.165 & $\mathbf{0 . 3 2 6}$ & 0.111 & 0.178 \\
\cline { 2 - 8 } & $\begin{array}{c}P- \\
\text { value }\end{array}$ & 0.279 & 0.304 & 0.173 & $\mathbf{0 . 0 0 6} *$ & 0.362 & 0.140 \\
\hline \multirow{2}{*}{$\begin{array}{c}\text { Duratio } \\
\mathbf{n}\end{array}$} & $\mathrm{r}$ & $\mathbf{0 . 2 5 7}$ & $\mathbf{0 . 2 6 0}$ & 0.037 & 0.002 & 0.148 & $\mathbf{0 . 3 2 7}$ \\
\cline { 2 - 8 } & \begin{tabular}{c} 
value \\
\hline
\end{tabular} & $\mathbf{0 . 0 3 2} *$ & $\mathbf{0 . 0 3 0} *$ & 0.760 & 0.988 & 0.222 & $\begin{array}{c}\mathbf{0 . 0 0 6} \\
*\end{array}$ \\
\hline
\end{tabular}

*Correlation is significant at the 0.05 level

**Correlation is significant at the 0.01 level

Table (7): Correlation between total knowledge, attitude, practice scores among studied studied sample pre and post-program $(n=70)$.

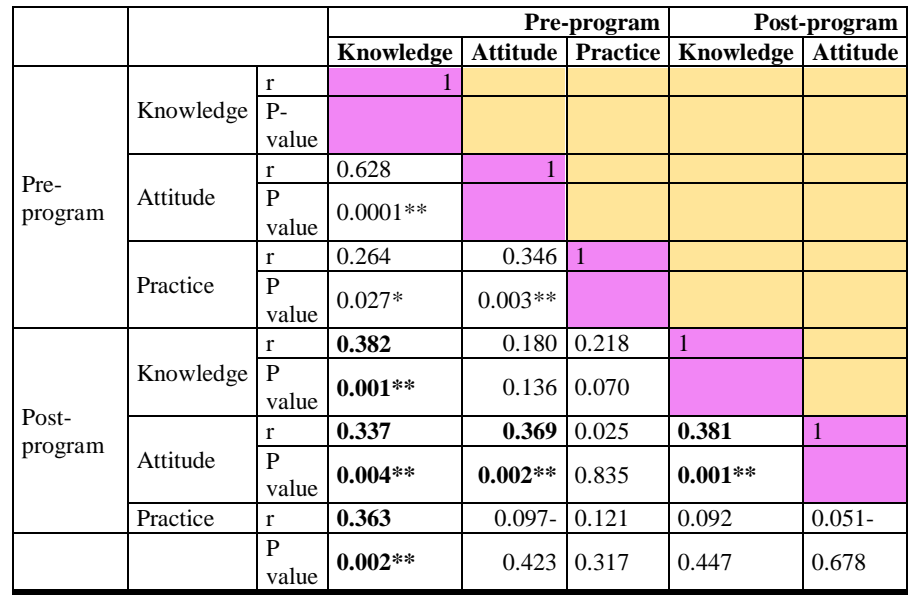

*Correlation is significant at the 0.05 level

**Correlation is significant at the 0.01 level

\section{Discussion}

Globally, nurses are a dynamic part of the healthcare system, and since the outbreak of COVID19, they have had challenging experiences and problems. Presently, in relation with other healthcare 
providers, they are in the frontline of the battle against the COVID-19 outbreak, and they are striving to help their patients in every sector. (García-Martín, et al 2020)

Maternity nurses play a vital role in healthcare setup in prevention, infection control, isolation, continuous monitoring of the patients and because of their unique patient facing nature, there are occupational risks to providing care during the COVID-19 outbreak (Smith et al, 2020).

This study aimed to evaluate the effect of educational program on nurse's knowledge, attitude and practice regarding Covid- 19 at maternity care units

We hypothesized that maternity nurse's knowledge; attitude and practices will be better post application of educational program if compared with pre-program levels.

By looking to socio demographic data, it was found that the majority of the nurses aged 22-27 yrs. and more than half of them were diploma nurse while the majority of them have duration of work from 1-5 yrs. More than three quadrants of them didn't attend any training program. these results didn't affirm the study of (Said et al, 2021) who found that one third of the sample age was between thirty and fourty years and the majority of them had bachelors education and less than half of them have less than 5 year's of experience also these results contradicted with (Al-Dossary, et al 2020) and mentioned that the mean age of the nurses was 33.92 ( $\mathrm{SD} \pm 7.22$ ). More than two thirds of the studied sample had bachelor's degrees. This may be due to the new appearance of the disease and rapid spread around the world.

In relation to sources of information, results of the present study revealed that near two thirds of the sample get their information from TV, Radio, these results agreed with (Huynh, et al, 2020) who found that the main sources of COVID-19 information among nurses were social media and the Ministry of Health website.

On the other hand this disagreed with (Nemati, et al., 2020) found that the sources of information for the nurses were the World Health Organization and the Ministry of Health and media. This may render to that the Egyptian media \&TV is keen to improve awareness of the Egyptians about Covid 19 epidemic to help spreading of the disease.

Nurses in the present study showed a highly significant difference in relation to their level of knowledge pre versus post applied education program at $\mathrm{P}=0.0001$, these findings agreed with (Joshi, et al, 2020) reported that Over all three quadrants of nurses showed good knowledge and awareness about COVID19 post educational program. Also these findings are supported with (Abdollahpour \& Khadivzadeh, (2020) who concluded that Improving quality of care in pregnancy and childbirth, as well as educating, supporting and training healthcare providers in control of infection epidemic need to be prioritized. This may be due to the need of nurses to know more and more about new developments of the disease as a result of its rapid spread and to improve their knowledge and quality of care at different maternity care units to help protect themselves, their families and their patients because hospitalized patients more prone to infection (Nosocomial infection)

According to attitude of nurses toward Covid 19, the current study proved that there was a highly significant difference between pre and post program nurses attitude. As positive attitude was observed post educational program toward care of confirmed or suspected women, these findings goes with the same direction of the study of (Abdel Wahed, et al., 2020) 
who observed among allied health workers positive attitude than physicians in many attitude items related to the government's role in diagnosis, treatment, and dealing with COVID-19 infections.

Also agreed with (Al Reshidi, 2020) who founded that the majority of nurses have positive attitude towards COVID-19. On the other hand contradicts with (Huynh, et al., 2020) and reported that Only nearly all of the nurses agree to isolate affected patients if it was needed. These results may be due to different socio demographic area and a lack of knowledge among nurses about important prevention and isolation strategies. And this stress on the need for the present educational program.

Regarding total scores of nurses practices, it was found that the majority of the sample have competent practices post educational program if compared to preprogram with highly statistical significant difference at $\mathrm{P}=0.0001$, these findings agreed with (Sahiledengle, $\mathrm{B}$, 2019), (CDC, 2020) who reported that all healthcare facilities that provide obstetric care must ensure that their personnel are correctly trained and capable of implementing recommended infection control interventions, including the use of personal protective equipment. Individual healthcare personnel should ensure they understand and can adhere to infection control requirements regarding Covid- 19. Also, (AlDossary, et al 2020) reported higher preventive practices in dealing with COVID-19 post intervention.

Regarding correlation between nurse's socio demographic data with their level of knowledge, practice and attitude, it was found that there was a positive correlation between nurse's knowledge and their age, educational level and years of experiences.

These results agreed with (Said et al, 2021), who found that there was highly statistically significant positive correlation between knowledge and socio demographic characteristic (age, education, and experience) pre and post program $p<0.001$. also match with the study of (Asif, 2019) who found that nurses with a bachelor's degree had better prevention and perception towards COVID-19 compared to other educational backgrounds. And nurses with master's degrees have positive clinical roles, with higher-level clinical competence and more knowledge than bachelor's degree nurses.

on the other hand results of ((Nemati, et al., 2020) didn't match the current findings found that the total knowledge score was not affected by age and education level and it was not significantly different between nurses with less or more work experience. Also contradicts with (Kamineni, et al, 2020) and concluded that here was no significant relationship between levels of knowledge with their socio demographic variables age, gender, education. It is possibly due to differentiation between different areas of residence.

Also a positive correlation was observed between nurse's attitude with their age and years of experiences; this is supported by the findings of (Huynh, et al., 2020) who observed highly significant positive correlation between attitude and demographics characteristics pre-program. From the researchers point of view, this correlation is due to the older the nurse the more experience acquired and the best attitude followed. While these results disagreed with (Amanya, 2020) who found that there was no statistically significant relationship between Covid-19 compliance with participants socio demographic data.

In addition the present study showed a positive fair relation between nurses practices with their age and years of experience also at $\mathrm{P}=0.004 \& \mathrm{P}=0.006$ pre and post program application respectively, these results match with the results of (Said et al, 2021) who found a highly significant correlation between practice and 
demographics characteristics (education, experience, and job) pre- and post-program $\mathrm{p}$ value $<0.001$. but contradicts with (Amanya, 2020) who found that the socio-demographic characteristics of health workers, including age, sex, education level, occupation, working hours and work experience, had no statistically significant relationship with Covid-19 knowledge or compliance.

Regarding correlation between KAP, the current study revealed that there was a positive association between KAP post educational program and also between knowledge and attitude and between knowledge and practice. This came in accordance with (Mbachu, et al., 2020) who found that a significant relationship between knowledge and practice implies that knowledge of all health workers should be improved to enhance the use of preventive practices. Also agreed with (Alrubaiee, et al., 2020) who revealed that the majority of respondents had a highperformance level of preventive behaviours towards COVID-19, which could be attributed to the having an adequate level of knowledge and awareness among the respondents towards COVID-19.

\section{Conclusions}

Based on the above mentioned, it could be concluded that providing educational programs about COVID-19 for maternity nurses is effective in improving knowledge, attitude, and practices. Also there was a positive correlation between nurse's knowledge and their age, educational level and years of experiences. In addition a positive correlation was observed between nurse's attitude with their age and years of experiences. While the current study revealed that there was a positive association between KAP post educational program.

\section{Recommendations}

Applying further wide range educational programs for whole nursing staff, nursing supervisors, and workers. These programs help keep themselves, their families, and patients safe from infection.

It is highly recommended that nurses should attend different training programs regarding Covid- 19 as an obligatory activity for them.

$\mathrm{MOH}$ should constantly updates its website and obligates healthcare providers to be aware of COVID19 updates.

\section{References}

Lotfi M, Hamblin MR, Rezaei N. COVID-19: transmission, prevention, and potential therapeutic opportunities. Clin Chim Acta. 2020; 508:254266. doi:10.1016/j.cca.2020.05.044.

Guan WJ, Ni ZY, Hu Y, Liang WH, Ou CQ, He JX, Liu L, Shan H, Lei CL, Hui DS, Du B. Clinical characteristics of 2019 novel coronavirus infection in China. MedRxiv. 2020 Jan 1.

World Health Organization. Coronavirus disease (COVID2019) situation reports 2020 [Available from: https://www.who.int/emergencies/diseases/ novel-coronavirus-2019 accessed 4 August 2020.

Rothan, H. A., \& Byrareddy, S. N. The epidemiology and pathogenesis of coronavirus disease (COVID19) outbreak. Journal of autoimmunity. (2020).

Shahnaz, S., Arain, M. I., Anwar, K., \& Anwar, R. Assessment of Knowledge Believes and Myths Regarding the use of mask inCOVID-19 Outbreak in Karachi Pakistan. Bulletin of Pharmaceutical Sciences. Assiut. (2020)

Zhong, B., Luo, W., Li, H., Zhang, Q., Liu, X., Li W., Li, Y. (2020). Knowledge, attitudes, and practices towards COVID-19 among Chinese residents during the rapid rise period of the COVID-19 outbreak: a quick online cross-sectional survey. Int. J. Biol. Sci. 2020; 16(10): 1745-1752. 
Wang D, Hu B, Hu C, Zhu F, Liu X, Zhang J, Wang B, Xiang H, Cheng Z, Xiong Y, Zhao Y, Li Y, Wang X, Peng Z. Clinical Characteristics of 138 Hospitalized Patients With 2019 Novel Coronavirus-Infected Pneumonia in Wuhan, China. JAMA. 2020 Mar 17; 323(11):10611069. doi: 10.1001/jama.2020.1585. PMID: 32031570 ; PMCID: PMC7042881.

Louay Labban, Nasser Thallaj1 and Abear Labban,: Assessing the Level of Awareness and Knowledge of COVID 19 Pandemic among Syrians, iMedPub Journals, 2020Vol.12 No.2:8.

García-Martín M, Roman P, Rodriguez-Arrastia M, DiazCortes MD, Soriano-Martin PJ, Ropero-Padilla C. Novice nurse's transitioning to emergency nurse during COVID-19 pandemic: a qualitative study. Journal of Nursing Management. 2020. 4(2):34-42. https:// doi.org/10.1111/jonm.13148

Smith GD, Ng F, and Li WHC. COVID-19: Emerging compassion, courage and resilience in the face of misinformation and adversity. Journal of Clinical Nursing 2020; 29(9-10):1425.

Said Amira Refaat, Eman Mohammed Abd Elhakam, Somaya Ouda Abd Elmoneim: educational program for maternity nurses regarding precautionary and preventive measures at labor unit during covid 19 (2021) Volume 12, Issue 2, February, pp. 104-123

Al-Dossary, R. Alamri, M., Albaqawi, H., Al Hosis, K. Aljeldah, M.,Aljohan, M, Aljohani, K., Almadani, N., Alrasheadi, B., Rawaih Falatah, R., and Almazan, J. Awareness, Attitudes, Prevention, and Perceptions of COVID-19 Outbreak among Nurses in Saudi Arabia, Int J Environ Res Public Health. 2020 Nov; 17(21): 8269.

Huynh G, Nguyen TNH, Tran VK, Vo KN, Vo VT, and Pham LA. Knowledge and attitude toward COVID-19 among healthcare workers at District 2 Hospital, Ho Chi Minh City. Asian Pac J Trop Med 2020; 13. doi: 10.4103/1995- 7645.280396

Nemati, M., Ebrahimi,B. and Nemati, F. Assessment of Iranian Nurses' Knowledge and Anxiety Toward COVID-19 During the Current Outbreak in Iran, Arch Clin Infect Dis, 2020 In
Press:e102848.Available at https://www.researchgate.net/publication/34027 8359_Assessment_of_Iranian_NurseKnowledge _and_Anxiety_Toward_COVID

19_During_the_Current_Outbreak_in_Iran

Joshi, K.P., Madhura, L., and Jamadar,D. Knowledge and awareness among nursing students regarding the COVID-19: a cross sectional study, International Journal of Community Medicine and Public Health 2020 7(6)1:4 available at https://www.researchgate.net/publication/34195 1661_Knowledge_and_awareness among nursing_students_regarding_the_COVID19_a_cross_sectional_study.

Abdel Wahed, W.Y., Hefzy, E.M. Ahmed, M.I. and Hamed, N.S. Assessment of Knowledge, Attitudes, and Perception of Health Care Workers Regarding COVID-19, A Cross-Sectional Study from Egypt, J Community Health. 2020 Jul 7: 1-10. Available at https://www.researchgate.net/publication/34275 4066_Assessment_of_Knowledge_Attitudes_an d_Perception_of_Health_Care_Workers_Regard ing_COVID 19_A_CrossSectional_Study_from_Egypt

Al Reshidi, N.M. Assessment of Saudi nurses knowledge, attitude and anxiety towards COVID19 during the current outbreak in KSA, IOSR Journal of Nursing and Health Science, Volume 9, Issue 3 Ser. XI (May - June 2020), PP 27-34.

Sahiledengle, B.Decontamination of patient equipment: nurses' self-reported decontamination practice in hospitals of southeast Ethiopia, BMC Research Notes (2019)12(1),392. https://www.researchgate.net/publication/33443 1280_Decontam nation_of_patient_equipment_nurses'_selfreport ed_decontamination_practice_in_hospitals_of_s outheast_Ethiopia

Centres For Disease and Control( CDC) (2020): Considerations for Inpatient Obstetric Healthcare Settings available at https://www.cdc.gov/coronavirus/2019ncov/hcp/inpatientobstetric- healthcareguidance.html 
Kamineni, S.R.T., Balu, P., Sivagananam, P., Chellapandian,P.,Chelladurai,U.M., Jayasheelan, $\quad$ V.P., Bopaiah, S.K.,Ravikumar,D.,Myneni, S., and Mohan,S.K.. Knowledge of COVID-19 among nursing and Allied health care professionals working in tertiary care hospital. International Journal of Research in Pharmaceutical Sciences, (2020) 11(SPL1), 103-109. https://doi.org/10.26452/ijrps.v11iSPL1.2233

Amanya, S., Nyeko, R., Obura, B.,Acen,J., Nabasirye, C., Oyella, F., Afayo,V.,\& Okwir,M., (2020) Knowledge and Compliance with Covid-19 Infection Prevention and Control measures among Health Workers in Regional Referral Hospitals in Northern Uganda: A cross-sectional Online Survey, available at https://assets.researchsquare.com/files/rs63627/v1/81d68abe-50a4-41c4872ac5b50e4b6762. Pdf

Asif, M.; Jameel, A.; Hussain, A.; Hwang, J.; Sahito, N. Linking Transformational Leadership with Nurse-Assessed Adverse Patient Outcomes and the Quality of Care: Assessing the Role of Job Satisfaction and Structural Empowerment. Int. J. Environ. Res. Public Health 2019, 16, 2381. [Cross Ref] [PubMed]

Mbachu, C.N.P., Azubuike, C.M.C., Mbachu, I.I. Ndukwu,C.I, Ezeuko, A.Y.A., Udigwe,I.B, Nnamani, C.P., Umeh,U.M., Ezeagwuna, D.A., Onah,S.K. Eze,H.O Okereke, U.C., and OrjiIfeanyi, E.N. COVID-19 infection: Knowledge, attitude, practices, and impact among healthcare workers in a South-Eastern Nigerian state $\mathbf{J}$ Infect Dev Ctries 2020; 14(9):943-952. doi:10.3855/jidc. 13248

Alrubaiee, G.G., Al-Qalah, T.A.H. \& Al-Aawar, M.S.A. Knowledge, attitudes, anxiety, and preventive behaviours towards COVID-19 among health care providers in Yemen: an online crosssectional survey. BMC Public Health 20, 1541 (2020). https://doi.org/10.1186/s12889- 02009644-y

Abdollahpour sedigheh, khadivzadeh: Improving the quality of care in pregnancy and childbirth with coronavirus (COVID-19): a systematic review.
Journal of maternal - fetal \& Neonatal Medicine. 2020 (1-9).

Nebraska Medicine (2020). COVID-19 Obstetric Testing Guideline. Nebraska Medicine is conducting universal testing of patients, transfers and admissions.

https://www.nebraskamed.com/sites/default/files /documents/covid19/universal-covid-testing-forpatients-final.pdf?date $=05202020$.

Nwafor J., Aniukwu J., Anozie B., and Ikeotuonye A. Knowledge and practice of preventive measures against COVID-19 infection among pregnant women in a low-resource African setting. available at: https://www.researchgate.net/publication/34078 8790. (2020)

Lancet T. 2020: unleashing the full potential of nursing. Lancet (London, England). 2019; 394(10212):1879.

CSSE J. Coronavirus COVID-19 Global Cases by the Center for Systems Science and Engineering (CSSE) at Johns Hopkins University (JHU). 2020. 